\title{
Word Order and Information Structure
}

\author{
Ad Neeleman and Hans van de Koot (UCL)
}

\section{Introduction}

Free word order phenomena have long been a problem in generative approaches to syntax, given the widespread assumption that linguistic representations are subject to some kind of economy. A common solution is based on the idea that the optionality is only apparent and that alternations are in fact regulated by information-structural (IS) constraints. That is to say, alternate word orders map onto distinct IS-representations. Indeed there is very strong evidence from constructions in various languages that mappings of this type exist. The general problem of how structures map onto interpretations is very complex, however, and it is therefore not surprising that an overarching theory of possible mapping is currently lacking.

The complexity of the problem has two sources. First, word-order variations are not generated by a single syntactic process. There are several potential syntactic competitors, such as active vs passive structures, structures with and without A-scrambling, structures with and without A'-scrambling, structures with and without clitic doubling, and so on. Along this syntactic dimension there is a problem of demarcation. For example, although active vs passive might be directly relevant to IS, many languages feature optional movement to the subject position in passive structures, and hence the real contrast relevant to IS might be between A-movement and lack thereof.

A second source of complexity has to do with the dimension of information structure. What is the range of relevant interpretations and how are these connected to each other? There seems to be general agreement that a distinction must be made between topic and focus. However, some authors believe that an additional distinction must be made between contrastive topic and focus on the one hand and plain topic and focus on the other. A different analytical tradition treats contrastive topics as topics containing a focus, potentially leaving no space for the notion of contrastive focus.

Work on the interface between syntax and information structure requires that we make decisions not only on these matters but also on the nature of the mapping system itself. Do we require that there is a one-to-one mapping between interpretations and syntactic configurations, do we allow one-to-many or many-to-one mappings from syntax to IS, or do we permit both of these options, resulting in many-to-many mappings?

Progress with the overall project requires two types of work. On the one hand, detailed empirical studies are necessary. For these one wants to acknowledge as many distinctions as possible on both the syntax and IS dimensions. On the other hand, bold theoretical work is required that aims to test restrictive hypotheses about available syntactic operations, available IS-primitives, and their mapping. Space does not permit us to undertake a full overview of known data. What we will do instead is evaluate some initial cross-cutting generalizations on the basis of a rough classification of syntactic operations and ISprimitives. Operations will be divided into those that are A-related, those that are A'-related, those that involve doubling with a pronoun or clitic, and finally those that involve extraposition. The IS-primitives we assume are topic, focus, contrast and givenness. We are well aware of the limitations of this exercise. 


\section{A-Related Phenomena}

Since the early 1990s a consensus has developed that certain scrambling phenomena involve A-positions. Early research on scrambling argued for a uniform A'-movement analysis (Bennis and Hoekstra 1984, Saito 1985, Hoji 1985), but further empirical discoveries (see, for instance, Webelhuth 1989, Ueyama 1994) provided evidence for A-related scrambling, analyzed in terms of movement (Vanden Wyngaerd 1989, Fanselow 1990, Mahajan 1990), base generation (Bayer and Kornfilt 1994, Neeleman 1994, Fanselow 2001), or a combination of the two (Zwart 1993).

There are three rough classes of potential analyses of the IS effects of A-scrambling. The first account assumes that A-scrambling takes place in order to generate an intonational pattern that matches the requirement that given material is destressed, or the requirement that focus attracts stress ((Zubizarreta 1998), Costa 1998, Cruz-Ferreira 1998, Neeleman and Reinhart 1998, Frascarelli 2000, İşsever 2003, Samek-Lodovici 2005). The second account takes IS features to be syntactic triggers for movement (Mahajan 1990, De Hoop 1992, Adger 1994, Runner 1995, Frey 2004, Broekhuis 2008). Finally, there are approaches that treat scrambling as an optimization for the LF interface. On this view, scrambling is either base-generated or a syntactically optional movement (possibly triggered by an optional edge feature) (Müller 1998, Haider and Rosengren 2003, Neeleman and Van de Koot 2008). We will not evaluate these alternatives here, but concentrate on the interpretive effects of Ascrambling.

In all cases of word order alternation, it is necessary to distinguish the neutral order from any marked orders. From the perspective of syntactic theory, neutral word order can be said to obtain if (i) arguments are merged in a minimal structure and in accordance with the thematic hierarchy and (ii) no phrasal movements take place other than those required to license the thematic and case properties of arguments. Of course, the fact that the syntactic analysis of neutral word order is straightforward does not imply that it is a simple matter to find out the neutral order of a given structure in a given language (see, for example, Haider and Rosengren 2003 on German and Titov 2012 on Russian). In those cases where it has been possible to uncover the neutral order, it appears that interpretive effects associated with word order alternations typically result from a rule that refers to the marked order. Any interpretive effects associated with the neutral order are due to blocking: the neutral order cannot always have the special interpretation of the marked order, but otherwise its interpretation is free.

When A-related order alternations appear to be triggered by IS considerations, they conform to the empirical generalization in (1). This generalization goes back to Hermann Paul and work in the Prague School and has since been endorsed by a range of authors (Clark and Clark 1977, Clark and Haviland 1977, Gundel 1988, Skopeteas and Fanselow 2010, a.o.).

\section{Generalization 1 (Given-before-New)}

If a language uses word order alternations to mark givenness, then in the marked order the given material precedes the new material.

Notice that this generalization mentions word-order alternation; it is therefore silent about givenness marking through clitic doubling. We will return to clitic doubling and clitic rightdislocation later in this chapter.

Generalization 1 is supported by considerable crosslinguistic evidence. The effect is typically related to a local reordering, usually referred to as scrambling. Dutch, for example, allows inversion of arguments and adjuncts. As the following example shows, this inversion can be motivated by givenness (see Neeleman and Van de Koot 2008): 
Hoe zit het met je review van dat boek van Haegeman?

'How are you progressing with your review of that book by Haegeman?'

a. \#Nou, ik denk dat ik eerst zorgvuldig het boek van Haegeman ga lezen. Well, I think that I first carefully the book by Haegeman go read

b. Nou, ik denk dat ik eerst het boek van Haegeman zorgvuldig ga lezen. Well, I think that I first the book by Haegeman carefully go read 'Well, I think that I will first carefully read Haegeman's book.'

The generalization extends to subjects and to indirect objects (not shown here).

Czech allows reordering of subjects and objects motivated by givenness. Thus, the neutral SVO order can be used in all circumstances, except when the object is given and the subjects new. Kucerova (2007) gives the following examples to demonstrate this:

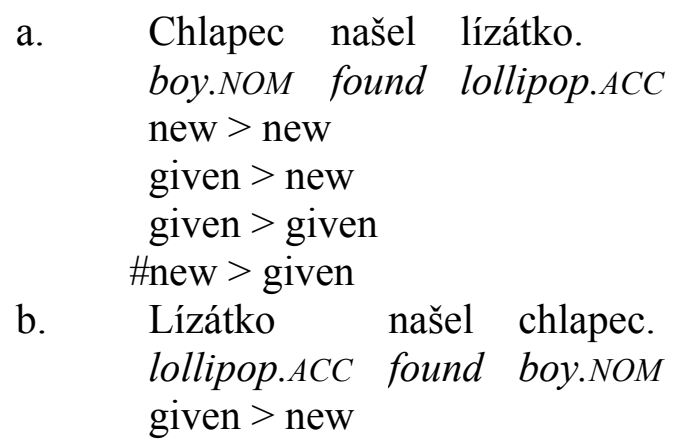

The same pattern is found in Russian (Titov 2012), which - like Czech - requires a given object to scramble across a new subject:

(4) Kto poceloval Katju?

'Who kissed Catherine?'

$\begin{array}{llll}\text { a. } & \text { \#Anja } & \text { pocelovala Katju } \\ & \text { Anja } & \text { kissed } & \text { Katju.ACC } \\ \text { b. } & \text { Katju } & \text { pocelovala Anja } \\ & \text { Katju.ACC } & \text { kissed Anja } \\ & \text { 'Anja kissed Catherine.' }\end{array}$

While in Czech and Russian givenness marking seems obligatory where possible, this is less clear for Dutch, where obligatoriness depends on the choice of adverbial. In particular, scrambling across a manner adverbial like zorgvulding 'carefully' appears to be obligatory, while scrambling across higher-level adverbs seems optional. In (2b) the DP surfaces below eerst 'first', but it may also scramble across the second adverbial (for many speakers this is true whether the manner adverb is present or not):

Hoe zit het met je review van dat boek van Haegeman?

'How are you progressing with your review of that book by Haegeman?'

Nou, ik denk dat ik het boek van Haegeman eerst zorgvuldig ga lezen.

Well, I think that I the bookby Haegeman first carefully go read

One potential explanation for this difference is that scrambling is domain-bounded, with manner adverbials obligatorily merged inside this domain, whereas higher-level adverbials are optionally merged outside it. 
In the languages discussed so far, then, there is evidence for obligatory givenness marking through scrambling: where the neutral order would place new information before given information, a local inversion must take place. The literature suggests that this is not a universal property of givenness marking through word order, however. Lenerz (1977) shows that scrambling in German double-object constructions is possible but not obligatory in cases where new information precedes given material in the base. Thus, examples like the following are both fully grammatical:

(6) Wem wollte der Richter den Jungen entziehen? Ich denke ...'

'From whom did the judge want to take the boy away? I think ...'
dass er dem
VATER den
Jungen
entziehen
that he the.DAT father the. ACC boy
b. dass er den Jungen dem VATER
take.away wanted
that he the.ACC boy
the.DAT father
entziehen wollte.
take.away wanted

However, it is not possible for scrambling to create an order in which new information precedes given material:

Wen wollte der Richter dem Vater entziehen? Ich denke ...'

'Who did the judge want to take away from the father? I think ...'
den JUNGEN
entziehen wollte.
that he the.DAT father the.ACC boy
take.away wanted
b. \#dass er den JUNGEN dem Vater
entziehen wollte.
that he the.ACC boy
the.DAT father
take.away wanted

It is not clear to us whether all native speakers fully share Lenerz's judgments. While the contrast in (7) is robust, not all speakers consulted by us find (6a) completely felicitous on a neutral intonation. The example is generally accepted if dem Vater receives contrastive stress. This makes it difficult to say with absolute certainty whether A-related scrambling in German is indeed optional. One analytical possibility that suggests itself is that it is in fact obligatory and that the order in (6a) is derived from the A-scrambling structure in (6b) through subsequent A'-scrambling of dem Vater.

If we accept the standard description of the data based on Lenerz, German can be said to have optional marking of givenness. An alternative description, endorsed by Lenerz himself, is that narrowly focused constituents resist scrambling. Notice, however, that constituents that are part of a larger focus, and that are therefore neither narrowly focused nor given, cannot be scrambled either (unless contrastive). This supports the view that the operation is motivated by givenness.

$$
\begin{aligned}
& \text { Was wollte der Richter tun? Ich denke...' } \\
& \text { 'What did the judge want to do? I think ...' } \\
& \text { a. dass er dem Vater den Jungen entziehen wollte. } \\
& \text { that he the.DAT father the.ACC boy take.away wanted } \\
& \text { b. \#dass er den Jungen dem Vater entziehen wollte. } \\
& \text { that he the.ACC boy the.DAT father take.away wanted }
\end{aligned}
$$

Korean manifests a very similar pattern of givenness marking not only for direct and indirect objects, but also for object and subject (Choi 2008, 2009; Hwang Jackson 2008). Whereas the canonical word order SOV is acceptable in both contexts below, the scrambled OSV order is contextually appropriate only when the object is given. 
Maryga muettsseul haesseo?

'What did Mary do?'
a. Maryga chaegeul ilgutsseo
Mary-NOM book-ACC read-PAST
b. \#Chaegeul Maryga ilgutsseo
book-ACC Mary-NOM read-PAST
'Mary read a book.'

(10) Nuga chaegeul ilgutsseo?

'Who read the book?'
a. Maryga guchaegeul ilgutsseo
Mary-NOM book-ACC read-PAST
b. Guchaegeul Maryga ilgutsseo
book-ACC Mary-NOM read-PAST
'Mary read the book.'

Implicit in the above discussion is the assumption that scrambling operations relevant to givenness marking target an A-position:

(11) Generalization 2 (A-Relatedness)

If a language uses word order alternations to mark givenness, then in the marked order the given material appears in an A-position.

Further motivation for this generalization comes from the fact that in some languages passive can be used to mark givenness. For extensive discussion of this observation, as well as references and experimental studies supporting it across a range of languages, see Skopeteas and Fanselow 2010. One empirical domain that can be used to test the generalization in (11) concerns the first position in V2 languages. This position can be targeted by movement of an object and is generally taken to be an A'-position. One would therefore expect that the first position could not be used for givenness marking. For Dutch this is clearly the correct prediction. For German it appears to be correct as well. Skopeteas and Fanselow (2010) report that in an elicitation study their German participants consistently failed to produce object-first structures when the object is given and the subject new. However, an anonymous reviewer suggests that the reply in the following dialogue is grammatical:

(12) Shin: Wer hat den Artikel von Ad und Hans rezensiert?

Who has the article by Ad and Hans reviewed

'Who has reviewed the article by Ad and Hans?'

Caroline: Den Artikel von Ad und Hans hat CHOMSKY rezensiert.

the article by Ad and Hans has Chomsky reviewed

'Chomsky has reviewed the article by Ad and Hans.'

Given the generalization in (11), it must either be the case that the first position in a V2 clause can be an A-position or that the fronting operation in (12) is not motivated by givenness, but by some other property of the object (such as contrast or topichood; see Fanselow this volume for relevant discussion).

A final remark about A-scrambling is in order. The above should not be read as suggesting that the only possible motivation for this operation is givenness. Rather givenness is one possible motivation for local reordering. In addition, A-scrambling can take place to 
mark scope (Ruys 2001) or to allow relations of binding and secondary predication. In addition, there are effects of the Silverstein Hierarchy (Silverstein 1976). The picture that emerges is one in which A-scrambling can be motivated by a range of interacting factors, one of which is givenness. For elaborate discussion of the system that regulates the interplay of these factors in Russian, see Titov 2012.

We conclude this section with a brief discussion of an apparent counterexample to generalizations 1 and 2 . In a variety of languages, extraposition of constituents is possible. As far as we know, extraposition does not have a fixed information-structural effect. Dutch PP extraposition, for example, can be used if the PP is focused, but also if it is given. English heavy-NP shift, on the other hand, requires some kind of presentational focus. These are of course syntactically divergent operations, and it is conceivable that once a detailed syntax of extraposition is available, a systematic mapping to Information Structure will reveal itself. Be that as it may, these constructions do not seem to present a threat to the generalizations introduced above, as neither involves marking of given material.

There are, however, extraposition phenomena in specific languages that are problematic. The worst case we are aware of is provided by extraposition in Turkish. Kornfilt (2005) shows that this operation displays strong connectivity effects, incompatible with Amovement and probably compatible with A'-movement. Furthermore, Kornfilt notes that extraposition in Turkish is restricted to given material, a conclusion previously reached in İssever 2003. If the operation indeed marks givenness, it seems to go against generalization 1 (because it is rightward) and generalization 2 (because it targets an A'-position).

We do not know how to solve this issue, but there are several potential lines of analysis that could be explored. First, it is possible that the marking effect is only apparent, and results from other factors that conspire to make extraposition unavailable for foci and topics. A second option is that the marking effect of A-scrambling is restricted to a particular domain that excludes the position of extraposed material in Turkish. A third possibility, suggested by Kornfilt, is that the operation takes place in the PF-component. If so, generalizations 1 and 2 could be saved by stipulating that they pertain to surface syntax. Finally, one could explore the relationship between extraposition in Turkish and right dislocation (given that Turkish is a radical pro drop language). There are two reasons why this looks promising. As we will see in section 4, right dislocation is associated with givenness for independent reasons. Moreover, right dislocation displays connectivity effects (see Ott and De Vries 2013). These seem to us interesting issues for further research.

\section{A'-Related Phenomena}

In a variety of languages $\mathrm{A}^{\prime}$-movement applies to contrastive variants of topics and foci, either optionally or obligatorily. This has led many researchers to conclude that topic, focus and contrast are autonomous notions of information structure that interact in systematic ways in syntax (see Vallduví 1992, Rizzi 1997, Vallduví and Vilkuna 1998, Aboh 2004 and Frey 2004, amongst others). On this view, (aboutness) topic and (new information) focus are basic notions of information structure that can be enriched to yield a contrastive interpretation (see Vallduví and Vilkuna 1998, Molnár 2002, McCoy 2003, Giusti 2006, Neeleman et al. 2009, and Neeleman and Vermeulen 2012, amongst others).

We adopt the following operational definitions for topic, focus and contrast. Focus is defined as in Rooth 1992. It involves the choice among a set of alternative propositions that vary only in one position. Topic is defined in terms of aboutness (see Reinhart 1981). Again, we assume that it involves choice among a set of alternatives, but in this case the alternatives are alternative utterances that share the same proposition (Krifka 2007, Tomioka 2010). Contrast adds to these basic interpretations the information that one of the alternatives is not 
valid. In the case of contrastive focus this means that an alternative proposition is untrue; in the case of contrastive topic, this means that an alternative utterance cannot be used, either because the proposition it contains is untrue or because the speaker does not want to take responsibility for its truth value. These notions are discussed in more detail in chapter 1 of Neeleman and Vermeulen 2012.

Linguistic topics should be distinguished from expressions in the utterance that merely index the current topic of discourse (also known as 'familiar topics'). Consider the following discourse (double underlining marks topics):

(13)a. Maxine was introduced to the queen on her birthday.

b. She was wearing a special dress for the occasion.

In (13a), Maxine is a linguistic topic: it introduces a new topic of discourse. The initial comment about Maxine is that she was introduced to the queen on her birthday. The pronoun her in this comment is not a linguistic topic, but a category that indexes the topic. We take the same to be true of she in the continuation in (13b) (see Vallduví 1992, Lambrecht 1994 and Vallduví and Engdahl 1996 for discussion).

With this in place, the key generalization governing the distribution of topics and foci can be formulated as in (14). ${ }^{1}$

\section{Generalization 3 (No Derived Topic-Focus Mismatch)}

A contrastive focus may not undergo contrast-related movement out of a constituent containing a topic.

The pattern covered by Generalization 3 may be summarized as follows (restricting ourselves to crossing movements). ${ }^{2}$ In a structure without movement, the relative order of topic and focus is expected to be free (see (15)). If only one moves, a topic can cross an in-situ focus, but not vice versa (see (16)). If both topic and focus move, the topic invariably lands in a position higher than the focus (see (17)).

$$
\begin{aligned}
& \text { a. } \quad[\ldots \text { Topic } \ldots[\text {... Focus ...] }] \\
& \text { b. } \quad[\ldots \text { Focus ... }[\ldots \text { Topic ... }]] \\
& \text { a. } \quad\left[\text { Topic }\left[\ldots \text { Focus } \ldots\left[\begin{array}{ll}
\ldots t_{\text {Topic }} & . . .
\end{array}\right]\right]\right. \\
& \text { b. } \quad *\left[\text { Focus }\left[\ldots \text { Topic } \ldots\left[\ldots t_{\text {Focus }} \ldots\right]\right]\right] \\
& \text { a. [Topic [Focus } \left.\left[\begin{array}{lllll}
\ldots & t_{\text {Focus }} & \ldots & t_{\text {Topic }} & \ldots .
\end{array}\right]\right] \\
& \text { b. } \quad *\left[\text { Focus [Topic }\left[\begin{array}{lllll}
\ldots & t_{\text {Focus }} & \ldots & t_{\text {Topic }} & \ldots
\end{array}\right]\right]
\end{aligned}
$$

An illustration of the pattern in (15) through (17) can be provided using Dutch, a language with optional movement of contrastive categories. In Dutch, contrastive foci carry an Aaccent and contrastive topics a B-accent (Jackendoff 1972, Büring 2003, Van Hoof 2003). In addition, a hat contour can be used if the topic precedes the focus (Gussenhoven 1984). Following standard practice, we assume that in the answer to a wh-question, the constituent that corresponds to the wh-operator is a focus. If interpreted contrastively, it qualifies as a

\footnotetext{
${ }^{1}$ We abstract away from structures in which the topic belongs to an embedded clause while the moved focus is a constituent of a superordinate clause.

${ }^{2}$ A further contrast can be observed with movements that land below an IS category. A moved focus can land below an in situ topic but not vice versa. For reasons of space, we cannot discuss this pattern here, but arguably it follows from the account of the generalization in (14) outlined below.
} 
contrastive focus. Thus, de bonen 'the beans' in $(18 \mathrm{a}, \mathrm{b})$ should be classified as such. One circumstance in which a contrastive topic is used is when a participant in a conversation answers a question about an entity different from the entity the original question was about. Therefore, Wim ('Bill') in $(18 \mathrm{a}, \mathrm{b})$ is a contrastive topic. The unacceptability of (18b) shows that a focus may not move across a topic.

(18) Hoe zit het met FRED? Wat heeft HIJ gegeten?

'What about Fred? What did he eat?'

Nou, dat weet ik niet, maar ik geloof

'Well, I don't know, but I believe'

a. dat $\underline{\underline{\text { Wim}}}$ van de BONEN meer gegeten heeft dan vorig jaar.
that Bill from the beans more eaten has than last year
'that Bill has eaten more from the beans than last year.'
b. \#dat $[\text { van de BONEN }]_{1} \underline{\underline{\text { Wim }}} t_{1}$ meer gegeten heeft dan vorig jaar.
that from the beans Bill more eaten has than last year

The data in (19) show that, by contrast, a topic may follow an in situ focus or move across it.

(19) Hoe zit het met de SOEP? Wie heeft DIE gegeten?

'What about the soup? Who ate that?'

Nou, dat weet ik niet, maar ik geloof ...

'Well, I don't know, but I believe ...'

a. dat WIM van debonen meer gegeten heeft dan vorig jaar. that Bill from the beans more eaten has than last year

b. dat [pp van de bonen] WIM $t_{\mathrm{PP}}$ meer gegeten heeft dan vorig jaar. that from the beans Bill more eaten has than last year 'that Bill has eaten more from the beans than last year.'

Finally, the example in (20) shows that the illicit configuration created by movement of a focus across a topic can be repaired by subsequent movement of the topic, giving rise to the configuration in (17a).

(20) Hoe zit het met Jan z'n OUDERS? Welk boek heeft hij HEN gegeven?

'What about John's parents? Which book has he given to them?'

Nou dat weet ik niet. Maar ik denk ...

'Well, I don't know. But I think...'

dat $[\underline{\underline{z} \text { 'n kinderen }}]_{1}$ [ DIT boek $]_{2}$ Jan $t_{1}$ zeker $t_{2}$ niet zal geven.

that hischildren this book John certainly not will give

'that John will certainly not give his children this book.'

The opposite order of movement, which instantiates (17b), results in unacceptability:

(21) \#dat [ DIT boek $]_{2}[\text { z'n kinderen }]_{1}$ Jan $t_{1}$ zeker $t_{2}$ niet zal geven. that this book hischildren John certainly not will give 'that John will certainly not give his children this book.'

Generalization 3 is further supported by observations from a variety of other languages.

Shen (2010) shows that the pattern illustrated in Dutch can be replicated in Mandarin, which also has optional A'-movement. 
Vermeulen (2013) discusses Japanese topic-focus interaction. There is a requirement in this language that topics appear in the left periphery of the clause. This makes it impossible to test the behaviour of in situ topics. However, as expected, contrastive foci cannot move across a topic, either locally or to the left periphery higher clause. This instantiates the pattern in (15) and (16).

In Hungarian, as in Japanese, topics must appear in the left periphery. In addition, exhaustive foci must move leftward as well. Crucially, there are no structures in which an exhaustive focus moves across a topic (Brody 1990, Kiss 1998).

As a final illustration, consider Italian. As is well-known, this language allows cliticdoubled constituents to appear in the left periphery, both above and below moved foci. Significantly, the low clitic-doubled constituents cannot be interpreted as topics but must be discourse-anaphoric (they can, of course, be anaphoric to the current topic of discourse). Thus, we find the same pattern as in Dutch if the clitic-doubled constituent is interpreted is a genuine topic. The following example from Torregrossa (2012) illustrates this (see also Frascarelli and Hinterhölzl 2007):

(22) Il nonna ha lasciato la scacchiera ai suoi nipoti?

'Did grandfather leave the chess board to his grandsons?'
a. \#Non lo so, ma AI SUOI FRATELLI l'orologio l'ha lasciato not it know.1SG, but to his brothers the-clock it-has left
b. Non lo so, ma l'orologio AI SUOI FRATELLI l'ha lasciato not it know.1SG, but the-clock to his brothers it-has left
'I don't know, but he has left the clock to his brothers.'

What is interesting about the pattern in (15) to (17) is that it shows an interaction between topic and focus not just when they appear in derived positions, but also when one is in a derived position and the other has moved. This imposes important restrictions on the kind of analysis that can be used to account for the generalization in (14).

One way of explaining this pattern could be based on the widely accepted IS constraint in (23) that requires topics to be interpreted externally to foci. The background of for this constraint was already hinted at above, when following Krifka 2007 and Tomioka 2010 we defined topics as related to the utterance and foci as related to the proposition.

\section{Topic Peripherality}

Topics are external to foci in information structure.

What Generalization 3 seems to amount to is a ban on A'-scrambling operations that transform an underlying structure in which the c-command relation between topic and focus matches their relative positions at LF into one that creates a mismatch. In other words, A'movement may not lead to a violation of shape preservation in the sense of Williams 2003). There are a number of ways in which an analysis along these lines can be developed (see Neeleman and Van de Koot 2008, 2012, Bobaljik and Wurmbrand 2012, amongst others).

\section{Linking to a Preceding Pronominal Category}

Natural language allows several constructions in which a DP is linked to a coreferential pronominal. In this section we will look at a subset of these constructions in which the pronoun precedes the associated DP. Structures with the reverse order will be considered in the next section. 
The structures in which a DP is linked to a preceding pronominal are syntactically heterogeneous. In one type, clitic doubling, the DP appears to be located in a regular argument position. The pronoun is located in a c-commanding position and, as we will see, it seems to represent the DP it doubles in certain respects. In the other type, right dislocation, the pronoun may appear in a regular argument position or may have undergone some independently motivated shift, while the associated DP does not seem to be part of the core sentence. Nonetheless, these two types of structure seem to share the requirement that the DP can be construed as given. We will argue, however, that only clitic doubling truly marks givenness. The effect found with right dislocation has a different source also evident in other structures.

Clitic doubling has both syntactic and interpretational similarities with A-scrambling (see Sportiche 1992, 1996, Anagnostopoulou 1994, and Alexiadou and Anagnostopoulou 1997). Starting with the syntactic similarities, first, like scrambling, clitic doubling can repair WCO violations. Second, a pronoun contained in a category that A-scrambles across a ccommanding quantifier cannot be a bound variable. Clitic-doubling of the category containing the pronominal has exactly the same effect. Third, Principle $\mathrm{C}$ effects are ameliorated by A-scrambling of the category containing the R-expression across the ccommanding pronoun. Again, doubling of the relevant category has much the same effect. Fourth, like A-scrambling, clitic doubling can license floating quantifiers. Fifth, both Ascrambled and clitic-doubled phrases permit subextraction, indicating that they occupy an Aposition. Finally, clitic doubling and A-scrambling are both very local (see particularly Sportiche 1996 for detailed discussion of the locality properties of clitic doubling). The above syntactic similarities could be expressed through a theory that assumes movement in both types of structure. Sportiche $(1992,1996)$, for example, suggests that A-scrambling targets the specifier of a phonologically null agreement head, while in doubling constructions, the relevant head is realized as a clitic, with the doubled DP moving to its specifier in covert syntax. An alternative way of stating the same insight is to analyze the clitic as a special spell-out of the head of a movement chain. The moved category could either be a functional head in the double (Uriagereka 1988, 1995, Papangeli 2000) or the entire associated DP (Anagnostopoulou 2003, Harizanov, to appear; see also Kechagias 2011).

Anagnostopoulou (1994) provides further arguments for a unified approach to doubling and A-scrambling by considering their interpretational similarities. First of all, just like A-scrambling, clitic doubling is typically associated with givenness marking. In fact, Anagnostopoulou argues that both scrambling and clitic doubling obey Heim's 1982 Prominence Condition, so that the referent of the scrambled/doubled DP must already be present in the context/discourse; mere accommodation of a new DP as familiar does not license either scrambling or doubling. Furthermore, Anagnostopoulou shows that those DP types that cannot undergo scrambling for givenness cannot be doubled either, and that these exceptions are predicted by the Prominence Condition. They include so-called novel definites and definite objects of idioms that do not have independent reference. The empirical picture is complicated by the fact that scrambling can be motivated by factors other than givenness, such as scope. This has the consequence that there are cases of A-scrambling that do not have a parallel in clitic doubling. For example, universals can scramble for scope, but cannot be clitic doubled.

Given that the analyses of clitic doubling on the market either treat the phenomenon in terms of A-movement (see the references above) or in terms of agreement (see Borer 1984 for an early proposal), there is no anaphoric dependency between the clitic and its double. This is a good thing, because if there was such a dependency, clitic doubling would violate Principle C (on the assumption that the clitic c-commands its double) as well as Williams's (1997) Generalized Principle of Anaphoric Dependence (GPAD), which forbids a pronoun 
from entering into an anaphoric relation with a following DP, unless the pronoun is contained in an embedded clause.

Let us now turn to right dislocation. There is considerable evidence to support the conclusion that syntactically the phrase in right dislocation is an adjunct (Strozer 1976, Jaeggli 1982, 1986, Borer 1984). For example, unlike a clitic-doubled argument, a rightdislocated phrase is an island. In many languages clitic-doubled arguments and rightdislocated constituents can also be distinguished through word order, with clitic-doubled arguments showing a closer affiliation with the verb than right-dislocated material (see for example Vallduví 1992 for Catalan). Furthermore, right-dislocated material is optionally preceded by a clear prosodic break not found with clitic doubling, with the intonation peak of the sentence falling on some element preceding the right-dislocated phrase (Vallduví 1992; Zubizarreta 1998).

At first sight, the interpretive effect associated with right-dislocation also seems to be one of givenness marking. The example in (24) is inappropriate in answer to the question "Would you like a drink?", but fine in answer to "Would you like a glass of this 12-year old Glenlivet?"

(24) Nou, ik vind het altijd wel lekker, zo'n single malt. well I find it always rather nice such-a single malt 'Well, I always quite enjoy it, a single malt.'

This establishes that the element in right dislocation must be given when apparently associated with a pronoun. However, this does not imply that the right-dislocation structure itself is linked to givenness by rule. On the contrary, there are cases of right dislocation where givenness is clearly not a factor, namely when the associated category is an indefinite:

I met a famous person last night: Keith Jarrett.

The right-dislocated material in this example is linked to a discourse-new argument and provides additional information about the referent of that argument. Why should this difference between (24) and (25) exist?

In both (24) and (25), GPAD forbids an anaphoric dependency between the object and the right-dislocated category. There is independent reason to think that there is no anaphoric dependence in right-dislocation structures. (25) contains an indefinite and a proper name, neither of which can be used as an anaphoric category:

(26) a. $\# \mathrm{John}_{1}$ entered the bar. [A man $]_{1}$ was wearing a hat.

b. $\quad \#[\text { A man }]_{1}$ entered the bar. John 1 was wearing a hat.

It therefore follows that there is no anaphoric dependence in (25). Indeed, the interpretive effect of this example is best captured by a paraphrase that is specificational in nature:

I met a famous person last night. It was Keith Jarrett.

It can be shown that there is no anaphoric relation in (24) either. If there was one, the pronoun would have to be the anaphoric category. However, referring back to zo'n single malt 'such a single malt' requires the use of a weak masculine pronoun rather than the neuter pronoun het 'it'.

(28) Jan bood me zo'n single malt aan. Hij zette ' $m /{ }^{*}$ 't op tafel. 
John offered me such.a single malt PRT He put him/it on table

'John offered me one of those single malts. He put it on the table.'

However, the neuter pronoun is the one used in specificational copula constructions (cf. Het was zo'n single malt. 'It was one of those single malts.').

Given that there is no anaphoric dependency between the pronoun and the rightdislocated category in (24), the pronoun must be linked to an antecedent in discourse. This in turn explains why right dislocation with a pronoun requires givenness. This analysis makes it conceivable that the function of right dislocation has nothing to do with givenness, but is always to provide additional information about the referent of a preceding argument. This can be done for dramatic effect, as in (25), where postponing crucial information introduces an element of suspense that is resolved by the right-dislocated phrase. However, in the cases where the right dislocated phrase is linked to a pronominal element, the specification might be necessary because the speaker has made an anaphoric commitment that is too strong. This fits well with the traditional idea of right-dislocated elements as 'afterthoughts'.

We conclude this section by briefly returning to generalizations 1 and 2. Neither clitic doubling nor clitic right dislocation seems to go against these generalizations. Clitic doubling is arguably a structure used for givenness marking, but on at least some analyses it involves leftward A-movement. Clitic right dislocation is clearly not a leftward A-movement, but, as we have just seen, it is unlikely to be a structure used to mark givenness.

\section{Linking to a Following Pronominal Category}

In this section we will look at constructions in which a pronoun follows an associated DP. Structures with the relevant order come in different types. The literature usually distinguishes between Clitic Left Dislocation (CLLD), contrastive left dislocation (CLD) and hanging topic left dislocation (HTLD).
a. Afton ton andra dhen to ksero. this.ACC the.ACC man.ACC not 'm.ACC know.1SG
b. Die man die ken ik niet. that man that know I not
c. This man, I don't know him.

CLLD

The examples in (29a) and (29c) are from Grohmann 2002, while the example in (29b) is a Dutch translation of a German example given by this author. CLLD, CLD and HTLD are structurally different from each other. HTLD does not involve movement and as a result the construction lacks connectivity effects and does not exhibit island sensitivity. CLD is at the other end of the spectrum with respect to these two diagnostics: it shows both connectivity and island effects. The standard analysis treats the construction as resulting from operator movement of the d-pronoun (which must occur in the left periphery; Koster 1978a, 1978b). Another possible analysis might assume movement of the left-dislocated category across the d-pronoun, which itself may or may not have moved (see Van Hoof 1997 for a related proposal). A third option would be to treat the d-pronoun as the spell-out of an intermediate trace left behind by the dislocated category (Grohmann 2000). The status of CLLD is much less clear. On the one hand, it shows connectivity effects and sensitivity to some islands. On the other, it violates certain other island conditions (Cinque 1990). This situation has led to two types of analysis. Grohmann (2000) argues that CLLD involves A'-movement of the leftdislocated category, while Cinque (1990) and Anagnostopoulou (1994) argue that the left- 
dislocated category is base-generated in its surface position and linked to the clitic by a general process of chain formation.

Despite this heterogeneous syntactic characterization, the structures in (29) share a certain interpretive core. To begin with, in none of the three structures is the left-dislocated category subject to a requirement of givenness, as opposed to what we previously observed for right-dislocated categories (associated with a pronoun) and clitic-doubled categories. Lambrecht (1994) cites the French examples in (30) as evidence of this contrast, but the data have been replicated in various other languages.

(30) Husband and wife at dinner table; husband looks at food on his plate:

$\mathrm{H}: \quad$ Ça n'a pas de gout, ce poulet
that neg-has not of taste this chicken
'It has notaste, this chicken.'
$\mathrm{W}$ : Le veau, c'est pire.
the veal it-is worse
'Veal is worse.'

Lambrecht notes that it is felicitous to have ce poulet 'this chicken' in right dislocation in the husband's remark, because of its prominence in the situational context. This suffices to establish it as a given topic. In contrast, le veau 'veal' in the wife's reply is in left dislocation, a structure used to introduce new discourse topics. Lambrecht explicitly remarks that it would be highly infelicitous for the wife to use right dislocation, exactly because le veau is not contextually given.

The above does not imply that left-dislocated material cannot be given. CLLD in Italian can be used to mark so-called 'familiar topics' (see Frascarelli and Hinterhölzl 2007), which are indeed given. Similarly, CLD can be used if the left-dislocated is already the current topic of discourse:
A: Ken je die kerel aan de bar?
'Do you know that guy at the bar?'
B: Nee, die man die ken ik niet. no that man that know I not
'No, that man I don't know.'

A natural explanation for the interpretive difference between left and right dislocation is provided by GPAD. Recall that the order "pronoun ... DP" in a local domain does not permit an anaphoric dependency between pronoun and DP. Therefore, the pronoun must be linked to an antecedent already established in discourse, resulting in an apparent givenness effect. By contrast, the order "DP ... pronoun" allows a direct dependency and therefore does not impose any interpretive requirement on the DP, allowing it to be either given or new.

It seems to us that the only requirement that does hold of a category in left dislocation is that it cannot be interpreted as a focus:

\section{Generalization 4 (No Focus Resumption)}

A category in left dislocation cannot be interpreted as a focus.

The validity of this generalization in Italian is clear as foci are never doubled, while topics and given material can appear in left dislocation (see Frascarelli and Hinterhölzl 2007). The situation in Dutch is somewhat complicated and at first sight seems to go against 
generalization 4. In the exchange below, it would seem that die nieuwe $C D$ van Dylan 'that new CD by Dylan' provides the answer to the WH-question.

\footnotetext{
A: Zeg, Carel, wat heb je in de stad uiteindelijk gekocht?

'Hey, Charles, what did you end up buying in town?'

B: Nou, die nieuwe CD van Dylan die heb ik maar aangeschaft.

Well, that new $C D$ by Dylan that have I but bought

'Well, I bought that new CD by Dylan.'
}

However, the answer provided by speaker B requires a context in which speakers A and B have previously discussed potential CDs for future acquisition and the Dylan CD was among these. The answer remains neutral regarding other potential acquisitions and therefore does not involve a contrastive focus. Rather it has the interpretive properties of a contrastive topic, with the focus on the verb aangeschaft 'bought'.

Generalization 4 is also supported by data from Japanese. Both topics and foci in this language can occur in a left-peripheral position. In the case of topics, this is obligatory. However, there is an important difference between contrastive and non-contrastive topics, discussed in some detail by (Vermeulen 2013). If the topic is contrastive, its relation with the empty category is island-sensitive. This suggests that a contrastive topic in Japanese ends up in the left periphery as a result of movement. No island effects are observed with noncontrastive topics, suggesting that such topics are linked to a null pronoun. Indeed, this pronoun can be overtly realized in the right kind of context. Fronted foci, however, are always island-sensitive and can never be linked to an overt pronoun, confirming that foci have no access to left dislocation.

In the same vein, Warlpiri allows topics but not foci to be linked to a following pronominal category (see Legate 2002 for relevant discussion).

\section{Conclusion}

This chapter has explored the relation between word order and information structure. While much work remains to be done, we have argued that the following four generalizations give a good first approximation of the cross-linguistic data:

(34) Generalization 1 (Given-before-New)

If a language uses word order alternations to mark givenness, then in the marked order the given material precedes the new material.

(35) Generalization 2 (A-Relatedness)

If a language uses word order alternations to mark givenness, then in the marked order the given material appears in an A-position.

(36) Generalization 3 (No Derived Topic-Focus Mismatch)

A contrastive focus may not undergo contrast-related movement out of a constituent containing a topic.

(37) Generalization 4 (No Focus Resumption)

A category in left dislocation cannot be interpreted as a focus.

Of course, these generalizations should emerge as effects of deeper properties of the language faculty or human psychology. In some cases, plausible explanations seem to be available. 
Generalization 1 might ultimately be an effect of a general cognitive principle according to which integration of new information is easier if framed within old information (see Clark and Haviland 1977). Relevant experiments showing that the effect goes beyond language can be found in Clifton and Slowiaczek 1981.

This explanation of generalization 1 may also shed some light on generalization 2. If the early presentation of old inform facilitates the integration of new information, it makes no sense to move the old information far away from the material to be integrated. Such non-local shifts would undo much of the beneficial effect of the reordering, as the intervening material might itself not be relevant to integration of the new information. Local shifts tend to be brought about by A-movement, rather than A'-movement.

Generalization 3, we have suggested, is an effect of the interpretive properties of topic (an utterance-level notion) and focus (a proposition-level notion), in conjunction with general restrictions on the mapping between syntax and semantics (see Neeleman and Vermeulen 2012 for discussion).

The theoretical basis for understanding generalization 4 remains elusive.

\section{References}

Aboh, Enoch Oladé. 2004. The Morphosyntax of Complement-Head Sequences. Oxford University Press.

Adger, David. 1994. "Functional Heads and Interpretation". PhD dissertation, University of Edinburgh.

Alexiadou, Artemis, and Elena Anagnostopoulou. 1997. "Toward a Unified Account of Scrambling and Clitic Doubling." In German: Syntactic Problems - Problematic Syntax, edited by Werner Abraham and Elly Van Gelderen, 142-61. Tübingen: Max Niemeyer.

Anagnostopoulou, Elena. 1994. "Clitic Dependencies in Modern Greek". PhD dissertation, University of Salzburg.

- 2003. The Syntax of Ditransitives: Evidence from Clitics. Berlin: Mouton de Gruyter.

Bayer, Josef, and Jaklin Kornfilt. 1994. "Against Scrambling as an Instance of Move-Alpha." In Studies on Scrambling, edited by Norbert Corver and Henk van Riemsdijk, 17-60. Berlin: Mouton de Gruyter.

Bennis, Hans, and Teun Hoekstra. 1984. "Gaps and Parasitic Gaps." The Linguistic Review 4: $29-87$.

Bobaljik, Jonathan David, and Susi Wurmbrand. 2012. "Word Order and Scope : Transparent Interfaces and the 3/4 Signature." Linguistic Inquiry 43 (3): 371-421.

Borer, Hagit. 1984. Parametric Syntax: Case Studies in Semitic and Romance Languages. Dordrecht: Foris Publications.

Brody, Michael. 1990. "Some Remarks on the Focus Field in Hungarian." Ms., UCL. London.

Broekhuis, Hans. 2008. Derivations and Evaluations: Object Shift in the Germanic Languages. Berlin: Mouton de Gruyter.

Büring, D. 2003. "On D-Trees, Beans, and B-Accents." Linguistics and Philosophy 26 (5). Springer: $511-45$.

Choi, Hye-Won. 2008. "Beyond Grammatical Weight: A Corpus Study of Information Structure Effect on Dative-Accusative Order in Korean." Discourse and Cognition 15: $127-52$.

. 2009. "Ordering a Left-Branching Language: Heaviness vs. Givenness.” Korean Society for Language and Information 13: 39-56.

Cinque, Guglielmo. 1990. Types of A'-Dependencies. Cambridge, MA.: MIT Press. 
Clark, H., and E. Clark. 1977. Psychology and Language: An Introduction to Psycholinguistics. New York: Harcourt Brace Jovanovich.

Clark, H., and S. Haviland. 1977. "Comprehension and the Given New Contrast." In Discourse Production and Comprehension, edited by R. O. Freedle, 1-40. Hillsdale, NJ: Lawrence Erlbaum Associates.

Clifton, Charles, and Maria Slowiaczek. 1981. "Integrating New Information with Old Knowledge." Memory \& Cognition 9 (2): 142-48.

Costa, Joao. 1998. "Word Order Variation: A Constraint-Based Approach". PhD dissertation, HIL/Leiden University.

Cruz-Ferreira, Madalena. 1998. "Intonation in European Portuguese." In Intonation Patterns: A Survey of Twenty Languages, edited by Daniel Hirst and Albert Di Cristo, 167-78. Cambridge: Cambridge University Press.

De Hoop, Helen. 1992. "Case Configuration and Noun Phrase Interpretation". PhD dissertation, University of Groningen.

Fanselow, Gisbert. 1990. "Scrambling as NP Movement." In Scrambling and Barriers, edited by Günther Grewendorf and Wolfgang Sternefeld, 113-40. Amsterdam: John Benjamins.

- 2001. "Features, @-Roles, and Free Constituent Order." Linguistic Inquiry 32 (3): 405-38.

Frascarelli, Mara. 2000. The Syntax-Phonology Interface in Topic and Focus Constructions in Italian. Dordrecht: Kluwer Academic Publishers.

Frascarelli, Mara, and Roland Hinterhölzl. 2007. "Types of Topics in German and Italian." In On Information Structure, Meaning and Form, edited by Susanne Winkler and Kerstin Schwabe, 87-116. Amsterdam: John Benjamins.

Frey, Werner. 2004. "A Medial Topic Position for German.” Linguistische Berichte 198: 153-90.

Giusti, Giuliana. 2006. "Parallels in Clausal and Nominal Periphery." In Phases of Interpretation, edited by Mara Frascarelli, 163-86. Berlin: Mouton de Gruyter.

Grohmann, K.K. 2000. "A Radical View from the Left". PhD dissertation, University of Maryland.

Grohmann, KK. 2002. "Anti-Locality and Clause Types.” Theoretical Linguistics 28 (1): 4372.

Gundel, Jeanette K. 1988. "Universals of Topic-Comment Structure.” In Studies in Syntactic Typology, edited by Michael Hammond, Edith A. Moravcsik, and Jessica R. Wirth, 209-39. Amsterdam: John Benjamins.

Gussenhoven, Carlos. 1984. On the Grammar and Semantics of Sentence Accents. Dordrecht: Foris Publications.

Haider, Hubert, and Inger Rosengren. 2003. "Scrambling: Nontriggered Chain Formation in OV Languages." Journal of Germanic Linguistics 15 (3): 203-66.

Harizanov, Boris. to appear. "Clitic Doubling at the Syntax-Morphophonology Interface: AMovement and Morphological Merger in Bulgarian." Natural Language \& Linguistic Theory.

Heim, Irene. 1982. "The Semantics of Definite and Indefinite Noun Phrases". PhD Dissertation, Amherst: University of Massachusetts.

Hoji, Hajime. 1985. "Logical Form Constraints and Configurational Structures in Japanese". $\mathrm{PhD}$ dissertation, University of Washington.

Hwang Jackson, Kyuseek. 2008. "The Effect of Information Structure on Korean Scrambling". University of Hawaii.

İşsever, Selçuk. 2003. "Information Structure in Turkish: The Word Order-prosody Interface." Lingua 113 (11): 1025-53. 
Jackendoff, Ray. 1972. Semantic Interpretation in Generative Grammar. Cambridge: Cambridge University Press.

Jaeggli, Osvaldo. 1982. Topics in Romance Syntax. Dordrecht: Foris Publications.

. 1986. "Three Issues in the Theory of Clitics: Case, Doubled NPs, and Extraction." In The Syntax of Pronominal Clitics, edited by Hagit Borer, 15-42. New York: Academic Press.

Kechagias, Axiotis. 2011. "Regulating Word Order in Modern Greek: Verb Initial and NonVerb Initial Orders and the Conceptual-Intentional Interface". PhD dissertation, UCL.

Kiss, Katalin É. 1998. "Identificational Focus versus Information Focus." Language 74 (2): 245-73.

Kornfilt, Jaklin. 2005. "Asymmetries between Pre-Verbal and Post-Verbal Scrambling in Turkish." In The Free Word Order Phenomenon: Its Syntactic Sources and Diversity, edited by Joachim Sabel and Mamoru Saito, 163-80. Studies in Generative Grammar 69. Berlin: Mouton de Gruyter.

Koster, Jan. 1978a. Locality Principles in Syntax. Dordrecht: Foris Publications. . 1978b. "Why Subject Sentences Don't Exist." In Recent Transformational Studies in European Languages, edited by Samuel J. Keyser, 53-64. Cambridge, MA.: MIT Press.

Krifka, Manfred. 2007. "Basic Notions of Information Structure." In Interdisciplinary Studies on Information Structure Vol. 6, ISIS, WPS of SFB 632, edited by Caroline Féry, Gisbert Fanselow, and Manfred Krifka, 06:13-56. Interdisciplinary Studies on Information Structure. 2007. Potsdam.

Kucerova, Ivona. 2007. “The Syntax of Givenness”. PhD dissertation, MIT.

Lambrecht, Knut. 1994. Information Structure and Sentence Form. Cambridge: CUP.

Legate, J.A. 2002. "Warlpiri: Theoretical Implications". PhD dissertation, MIT.

Lenerz, Jürgen. 1977. Zur Abfolge Nominaler Satzglieder Im Deutschen. Tübingen: Narr Verlag.

Mahajan, Anoop. 1990. "The A/A-Bar Distinction and Movement Theory". MIT.

McCoy, Svetlana. 2003. "Connecting Information Structure and Discourse Structure through 'Kontrast': The Case of Colloquial Russian Particles -TO, ŽE , and VED '." Journal of Logic, Language and Information 12: 319-35.

Molnár, Valéria. 2002. "Contrast - from a Contrastive Perspective." In Information Structure in a Cross-Linguistic Perspective, edited by H. Hallelgard, Stig Johansson, Bergljot Beherens, and Cathrine Fabricius-Hansen, 99-114. Amsterdam/New York: Rodopi.

Müller, Gereon. 1998. Incomplete Category Fronting. Dordrecht: Kluwer.

Neeleman, Ad. 1994. "Complex Predicates". PhD dissertation, Utrecht University.

Neeleman, Ad, and Tanya Reinhart. 1998. "Scrambling and the PF Interface." In The Projection of Arguments, edited by Miriam Butt and W. Geuder, 309-53. Stanford, CA: CSLI.

Neeleman, Ad, Elena Titov, Hans Van de Koot, and Reiko Vermeulen. 2009. "A Syntactic Typology of Topic, Focus and Contrast." In Alternatives to Cartography, edited by Jeroen Van Craenenbroek, 15-51. Berlin: Mouton de Gruyter.

Neeleman, Ad, and H. Van De Koot. 2012. "Towards a Unified Theory of Contrast and Scope." In The Syntax of Topic, Focus, and Contrast: An Interface-Based Approach, edited by Ad Neeleman and Reiko Vermeulen, 39-76. Berlin: Mouton de Gruyter.

Neeleman, Ad, and Hans van de Van de Koot. 2008. "Dutch Scrambling and the Nature of Discourse Templates." The Journal of Comparative Germanic Linguistics 11 (2): 137-89.

Neeleman, Ad, and Reiko Vermeulen, ed. 2012. The Syntax of Topic, Focus and Contrast: An Interface-Based Approach. Berlin: Mouton de Gruyter. 
Ott, Dennis, and Mark De Vries. 2013. "Right-Dislocation as Deletion". Ms. University of Groningen.

Papangeli, Dimitra. 2000. "Clitic Doubling in Modern Greek: A Head-Complement Relation." UCL Working Papers in Linguistics 12: 473-99.

Reinhart, Tanya. 1981. "Pragmatics and Linguistics: An Analysis of Sentence Topics." Philosophica 27 (1): 53-94.

Rizzi, L. 1997. "The Fine Structure of the Left Periphery." In Elements of Grammar: Handbook in Generative Syntax, edited by Liliane Haegeman, 281-338. Dordrecht: Kluwer Academic Publishers.

Rooth, Mats. 1992. "A Theory of Focus Interpretation." Natural Language Semantics 1 (1): 75-116.

Runner, Jeffrey T. 1995. "Noun Phrase Licensing and Interpretation". University of Massachusetts.

Ruys, E. G. 2001. "Dutch Scrambling and the Strong-Weak Distinction." The Journal of Comparative Germanic Linguistics 4 (1): 39-67.

Saito, Mamoru. 1985. "Some Asymmetries in Japanese and Their Theoretical Implications". $\mathrm{PhD}$ dissertation, MIT.

Samek-Lodovici, Vieri. 2005. "Prosody-Syntax Interaction in the Expression of Focus." Natural Language \& Linguistic Theory 23: 687-755.

Shen, Zheng. 2010. "On Focus and Topic Interaction in Mandarin Chinese". MA Dissertation, UCL.

Silverstein, Michael. 1976. "Hierarchy of Features and Ergativity." In Grammatical Categories in Australian Languages, edited by R.M.W. Dixon, 112-71. Canberra: Australian Institute of Aboriginal Studies.

Skopeteas, Stavros, and Gisbert Fanselow. 2010. "Effects of Givenness and Constraints on Free Word Order." In Information Structure: Theoretical, Typological, and Experimental Perspectives, edited by Malte Zimmermann and Caroline Féry, 307-31. Oxford: Oxford University Press.

Sportiche, Dominique. 1992. "Clitic Constructions". Ms. UCLA. - 1996. "Clitic Constructions." In Phrase Structure and the Lexicon, edited by Johan Rooryck and Laurie Zaring, 213-76. Dordrecht: Kluwer Academic Publishers.

Strozer, Judith Reina. 1976. "Clitics in Spanish". PhD Dissertation, UCLA.

Titov, Elena. 2012. "Information Structure of Argument Order Alternations". PhD Dissertation, UCL.

Tomioka, Satoshi. 2010. "Contrastive Topics Operate on Speech Acts." In Information Structure: Theoretical, Typological, and Experimental Perspectives, edited by Malte Zimmermann and Caroline Féry, 115-38. Oxford: OUP.

Torregrossa, Jacopo. 2012. "Encoding Topic, Focus and Contrast: Informational Notions at the Interfaces". PhD Dissertation, University of Verona.

Ueyama, Ayumi. 1994. "Against the A/A'-Movement Dichotomy." In Studies on Scrambling: Movement and Non-Movement Approaches to Free Word-Order Phenomena, edited by Norbert Corver and Henk Van Riemsdijk, 459-86. Berlin: Mouton de Gruyter.

Uriagereka, Juan. 1988. “On Government”. PhD dissertation, University of Connecticut. . 1995. "Aspects of the Syntax of Clitic Placement in Western Romance." Linguistic Inquiry 26: 79-124.

Vallduví, Enric. 1992. The Informational Component. New York: Garland.

Vallduví, Enric, and Elisabet Engdahl. 1996. "The Linguistic Realization of Information Packaging." Linguistics 34 (3): 459-520. 
Vallduví, Enric, and Maria Vilkuna. 1998. "On Rheme and Kontrast." In Syntax and Semantics 29: The Limits of Syntax, edited by Peter Culicover and Louise McNally, 79-108. San Diego, CA: Academic Press.

Van Hoof, Hanneke. 1997. "Left Dislocation and Split Topics in Brabant Dutch." In Materials on Left Dislocation, edited by E. Anagnostopoulou, Henk Van Riemsdijk, and Frans Zwarts, 275-306. Amsterdam/Philadelphia: John Benjamins. 2003. "The Rise in the Risefall Contour: Does It Evoke a Contrastive Topic or a Contrastive Focus?" Linguistics 41 (3): 515-63.

Vanden Wyngaerd, Guido. 1989. "Object Shift as an A-Movement Rule." MIT Working Papers in Linguistics 11: 256-71.

Vermeulen, Reiko. 2013. "On the Position of Topics in Japanese." The Linguistic Review 30 (1): 117-59.

Webelhuth, Gert. 1989. "Syntactic Saturation Phenomena and the Modern Germanic Languages". PhD dissertation, University of Amherst.

Williams, Edwin. 1997. "Blocking and Anaphora." Linguistic Inquiry 28: 577-628.

- 2003. Representation Theory. Cambridge, MA: MIT Press.

Zubizarreta, Maria Luisa. 1998. Prosody, Focus and Word Order. Cambridge, MA.: MIT Press.

Zwart, C. Jan-Wouter. 1993. "Dutch Syntax: A Minimalist Approach". PhD dissertation, University of Groningen. 